\title{
Occurrences of six steroid estrogens from different effluents in Beijing, China
}

\author{
Yiqi Zhou • Jinmiao Zha • Yiping Xu • \\ Bingli Lei · Zijian Wang
}

Received: 13 August 2010 / Accepted: 11 April 2011 / Published online: 5 May 2011

(C) Springer Science+Business Media B.V. 2011

\begin{abstract}
Concentration levels of six natural and anthropogenic origin steroid estrogens, namely, diethylstilbestrol (DES), estrone (E1), estradiol (E2), estriol (E3), ethinylestradiol (EE2), and estradiol-17-valerate (Ev), from different effluents in Beijing were assessed. Sampling sites include two wastewater treatment plants (WWTPs), a chemical plant, a hospital, a pharmaceutical factory, a hennery, and a fish pool. In general, concentrations of estrogens in the effluents varied from no detection (nd) to $11.1 \mathrm{ng} / \mathrm{l}, 0.7$ to $1.2 \times 10^{3} \mathrm{ng} / \mathrm{l}$, nd to $67.4 \mathrm{ng} / \mathrm{l}$, nd to $4.1 \times$ $10^{3} \mathrm{ng} / \mathrm{l}$, nd to $1.2 \times 10^{3} \mathrm{ng} / \mathrm{l}$, and nd to $11.2 \mathrm{ng} / \mathrm{l}$ for DES, E1, E2, EE2, E3, and Ev, respectively. The concentration levels of steroid estrogens from different effluents decreased in the order of pharmaceutical factory and WWTP inlets $>$ hospital $>$ hennery $>$ chemical factory $>$ fish pool. This study indicated that natural estrogens E1, E2, and E3 and synthetic estrogen EE2 are the dominant steroid estrogens found in the different Beijing effluents. For source identification, an indicator $(\mathrm{hE}=\mathrm{E} 3 /(\mathrm{E} 1+\mathrm{E} 2+\mathrm{E} 3))$ was used to trace human estrogen excretion. Accordingly, hE in
\end{abstract}

Y. Zhou · J. Zha · Y. Xu · B. Lei · Z. Wang $(\bowtie)$

State Key Laboratory of Environmental Aquatic

Chemistry, Research Center for Eco-Environmental

Sciences, Chinese Academy of Sciences, PO Box 2871,

Beijing, 100085, People's Republic of China

e-mail: wangzj@rcees.ac.cn effluents from the hospital and WWTP inlets exceeded 0.4 , while much smaller values were obtained for the other effluents. Human excretions were the major contributor of natural estrogens in municipal wastewater. Estimation results demonstrated that direct discharge was the major contributor of steroid estrogen pollution in receiving waters.

Keywords Endocrine disrupting compounds • Steroid estrogens $\cdot$ Effluents $\cdot$ Sewage $\cdot$ Beijing

\section{Introduction}

Concern over endocrine-disrupting compounds (EDCs) has increased in recent years due to their adverse ecological and health effects. Included among EDCs, steroid estrogens of natural and anthropogenic origin are major contributors to endocrine-disrupting activity in both sewage effluent and surface water (Lai et al. 2000; Gomes et al. 2004). Human females experiencing long-term exposure to diethylstilbestrol (DES) increases risk of breast cancer and/or cervicovaginal cancer. Other abnormalities such as immune system disorders, psychosexual effects, and reproductive abnormalities have been linked to DES exposure (Ford et al. 1983; Giusti et al. 1995; Brown et al. 2006). From an ecotoxicological view, the estrogenic effects of steroid estrogens on test 
animals have been observed in the range of $0.2-$ $1 \mathrm{ng} / \mathrm{l}$, which are lower than those commonly detected in aquatic environments (Routledge et al. 1998; Legler et al. 2002; Zuo et al. 2005; Campbell et al. 2006; Labadie and Budzinski 2006; Zha et al. 2008). Consequently, steroid estrogens in water environments may pose a significant threat to aquatic life or those depending on such water (Purdom et al. 1994; Hansen et al. 1998; Sun et al. 2007; Ma et al. 2008).

In effluents, estrone (E1), $\beta$-estradiol (E2), and estriol (E3) are mainly excreted by humans and animals as conjugate estrogens in urine and feces, and are cleaved to free estrogen by bacteria (Ternes et al. 1999; Legler 2001). Up to $80 \%$ of ingested $17 \alpha$-ethinylestradiol (EE2), a major ingredient in contraceptive pills, is excreted as an unmetabolized conjugate. It has been estimated that approximately $30 \%$ of excreted EE2 originates from feces and $22-50 \%$ originates from urine (Reed et al. 1972; Ranney 1977; Maggs et al. 1983). Estradiol-17-valerate is used for the medical therapy of conditions such as amenorrhea, menopausal syndrome, reduction of milk secretion, and prostate cancer, yet its environmental behavior remains unclear. Although it has been abandoned recently for therapeutic use, synthetic DES was routinely used to prevent spontaneous abortion. Other potential sources of steroid estrogen are livestock feedlot effluent, agricultural run-off from sewage and manure fertilizer, and industrial production of steroidal estrogen products (Lintelmann et al. 2003; Orlando et al. 2004; Soto et al. 2004). Estrogens have been found widely in livestock waste, particularly the feces and urine of cattle, sows, and chickens (Travis et al. 2003). Additionally, steroidal compounds are used to develop single-sex populations of fish to optimize growth in aquaculture. Although fish gender is primarily controlled by genetics, it may be influenced by various environmental conditions, such as exposure to exogenous hormones or hormone-like chemicals. Thus, all-male and allfemale fish stock can be achieved through exposure to androgens and estrogens, respectively (Strussmann et al. 1996; Beardmore et al. 2001; Hurley et al. 2004).

Effluents from different sources represent significant estrogenic input to the aquatic environ- ment. The discharge of steroid estrogens into such environments depends largely on their incomplete removal during treatment processes (Belfroid et al. 1999; Baronti et al. 2000; D'Ascenzo et al. 2003). Our previous bioassay research demonstrated that industrial, domestic, and livestock wastewaters are important sources of estrogenic discharge in Beijing (Ma et al. 2008). However, the concentration levels of steroid estrogens in different effluents have not been clearly demonstrated. In the present study, we sampled different Beijing effluents to investigate the distribution of six steroid estrogens and determine their main donator in the aquatic environment.

\section{Materials and methods}

Study area and sampling sites

By 2010, the population of Beijing exceeded nineteen million people, placing significant impact on the quality of receiving waters due to run-off and sewage. We selected seven possible representative sources of estrogen discharge, with effluent sampling sites from two wastewater treatment plants (F and G), a chemical plant (B), a hospital (C), a pharmaceutical factory (D), a hennery (E) and a fish pool (A; Fig. 1). Details of the sampling strategies used are presented in Table 1 . We used a global positioning system (GPS) throughout the survey to locate sampling positions. The 24h composite water samples were collected using glass bottles, previously detergent-washed, acidrinsed, and dried at $120^{\circ} \mathrm{C}$ for $6 \mathrm{~h}$, with $5 \%(v / v)$ methanol added immediately after collection to prevent growth of microorganisms. Samples were stored at $4^{\circ} \mathrm{C}$ until extraction within $12 \mathrm{~h}$.

Both WWTPs ( $F$ and $\mathrm{G}$ ) receive mainly domestic wastewater (Table 2). Site F, which utilizes second activated sludge treatment $\left(\mathrm{A}^{2} \mathrm{O}\right)$, is located in the Fengtai district of Beijing, treats a mean flow of $200,000 \mathrm{~m}^{3}$ per day, and services a population of approximately 345,000 people. Four samples were collected including influent, primary effluent, nitrification effluent, and the last effluent in summer and two samples (influent and the last effluent) in winter in 2005. Site G, which 
Fig. 1 Sampling sites $(A$ fish pool, $B$ chemical plant, $C$ hospital, $D$ pharmaceutical factory, $E$ hennery, $F, G$ wastewater treatment plant)

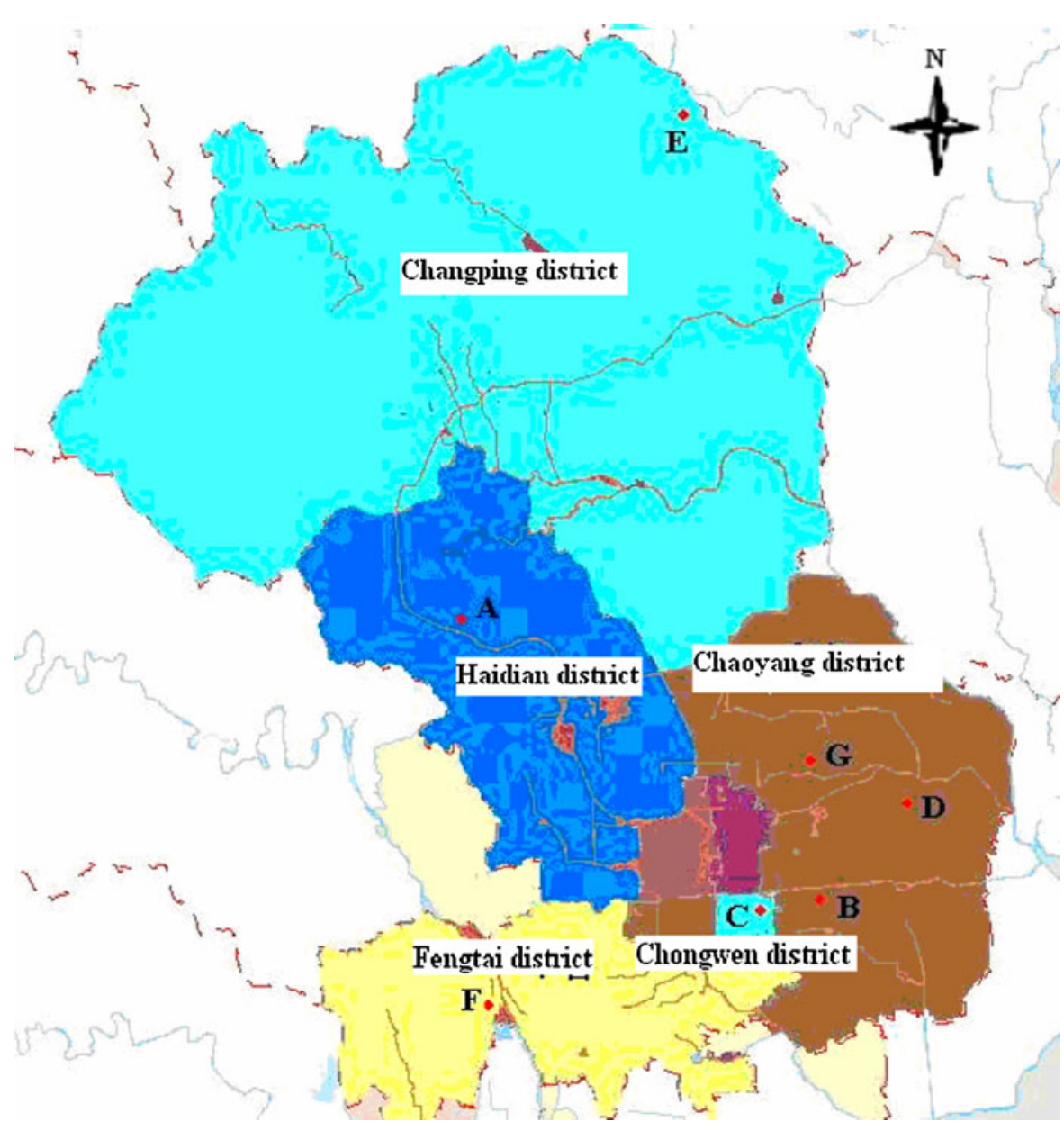

uses an oxidation ditch activated sludge treatment process, is located in the Chaoyang district of Beijing, treats a mean flow of $200,000 \mathrm{~m}^{3}$ per day, and services a population of approximately 480,000 people. Influent and effluent were collected from this WWTP in the summer of 2005.

Table 1 Details of sampling

\begin{tabular}{|c|c|c|c|c|c|}
\hline $\begin{array}{l}\text { Sampling } \\
\text { site }\end{array}$ & Sampling time & Site description & Type of sample & Longitude & Latitude \\
\hline A & $\begin{array}{l}\text { 18th, May, } 2005 \\
21 \text { st, October, } 2005\end{array}$ & Fish pool & Surface water & $116^{\circ} 20^{\prime} 07^{\prime \prime}$ & $40^{\circ} 00^{\prime} 20^{\prime \prime}$ \\
\hline B & $\begin{array}{l}\text { 15th, June, } 2005 \\
15 \text { th, November, } 2005\end{array}$ & Chemical plant & Wastewater & $116^{\circ} 29^{\prime} 22^{\prime \prime}$ & $39^{\circ} 53^{\prime} 29^{\prime \prime}$ \\
\hline $\mathrm{C}$ & $\begin{array}{l}\text { 16th, June, } 2005 \\
\text { 16th, November, } 2005\end{array}$ & Hospital & Wastewater & $116^{\circ} 28^{\prime} 78^{\prime \prime}$ & $39^{\circ} 52^{\prime} 98^{\prime \prime}$ \\
\hline $\mathrm{D}$ & $\begin{array}{l}\text { 1st, July, } 2005 \\
\text { 16th, November, } 2005\end{array}$ & Pharmaceutical factory & Wastewater & $116^{\circ} 34^{\prime} 35^{\prime \prime}$ & $39^{\circ} 55^{\prime} 27^{\prime \prime}$ \\
\hline $\mathrm{E}$ & 23rd, June, 2005 & Hennery & Wastewater & $116^{\circ} 23^{\prime} 91^{\prime \prime}$ & $40^{\circ} 27^{\prime} 26^{\prime \prime}$ \\
\hline $\mathrm{F}$ & $\begin{array}{l}\text { 13th, July, } 2005 \\
\text { 13th, December, } 2005\end{array}$ & WWTPa & Wastewater & $116^{\circ} 15^{\prime} 54^{\prime \prime}$ & $39^{\circ} 49^{\prime} 37^{\prime \prime}$ \\
\hline G & 7th, July, 2005 & WWTP & Wastewater & $116^{\circ} 30^{\prime} 37^{\prime \prime}$ & $39^{\circ} 57^{\prime} 40^{\prime \prime}$ \\
\hline
\end{tabular}

${ }^{\mathrm{a}} W W T P$ wastewater treatment plant 
Table 2 Relative information of selected wastewater treatment plants (WWTPs) in this study

\begin{tabular}{|c|c|c|c|c|c|c|c|c|}
\hline \multirow[t]{2}{*}{ WWTP } & \multirow[t]{2}{*}{ Inhabitants } & \multirow{2}{*}{$\begin{array}{l}\text { Loading, } \\
\mathrm{m}^{3} \text { day }^{-1}\end{array}$} & \multicolumn{2}{|c|}{$\mathrm{BOD}, \mathrm{mg} / \mathrm{l}$} & \multicolumn{2}{|c|}{$\mathrm{COD}, \mathrm{mg} / \mathrm{l}$} & \multicolumn{2}{|c|}{$\mathrm{SS}, \mathrm{mg} / \mathrm{l}$} \\
\hline & & & Inlet & $\overline{\text { Oulet }}$ & Inlet & $\overline{\text { Oulet }}$ & Inlet & Oulet \\
\hline$\overline{\mathrm{F}}$ & 345,000 & 200,000 & 222.8 & 2.6 & 461.9 & 48.3 & 252 & 4.4 \\
\hline $\mathrm{G}$ & 480.000 & 200,000 & 172.3 & 3.5 & 368.6 & 41.8 & 181.4 & 10.6 \\
\hline
\end{tabular}

The pharmaceutical factory sampling site has a 30-year history and is engaged in the development and production of five major products related to family planning administration, reproductive health medication, ophthalmic medication, hightech generic drugs and health care products, and biological products. It is one of China's premier research and development bases related to contractive and reproductive health pharmaceuticals.

The hennery is located in Xiaotangshan town, Changping district, Beijing. Founded in 1983, it was China's first large-scale modern chicken production enterprise and continues to operate. The chemical plant was built in 1958, a large-scale enterprise for the production of raw chemical materials. The hospital is located in Chongwen District, Beijing, and is a designated medical institution for basic medical care in Beijing. The fish ponds are located in Haidian District and include more than ten fish pools over 200 acres.

\section{Chemicals and materials}

The target steroidal estrogen compounds for this study included three natural estrogens, specifically, $\mathrm{E} 1, \mathrm{E} 2$, and E3, and three synthetic estrogens, specifically, EE2, DES, and $\beta$-estradiol-17-valerate (Ev). All target compounds were of the highest purity commercially available. E1, E2, EE2, and Ev were purchased from Sigma-Aldrich, USA. Both E3 and DES were purchased from Fluka, Netherlands. Derivatization reagents of bis(trimethyl)-trifluoroacetamide (BSTFA) containing $1 \%$ of trimethylchlorosilane (TCMS) and trimethylsilylimidazole (TMSI) were purchased from Supelco, USA, and Sigma-Aldrich, Germany, respectively. Surrogate standard 17- $\beta$-estradiol-16, $16,17-\mathrm{d}_{3}\left(\mathrm{E} 2-\mathrm{d}_{3}\right)$ was produced by $\mathrm{C} / \mathrm{D} / \mathrm{N}$ Isotopes (Montreal, Canada). Internal standard pyrene$\mathrm{d}_{16}$ was purchased from Supelco, USA. Acetone, $n$-hexane, dichloromethane (DCM), methanol
$(\mathrm{MeOH})$, ethyl acetate, and cyclohexane are of HPLC-grade and were purchased from Mallinckrodt, USA. Sodium sulfate (analytical reagent grade, Mallinckrodt USA) was sequentially rinsed with acetone, DCM, and hexane three times each, and completely dried in the fume hood. The dried sodium sulfate was baked at $450^{\circ} \mathrm{C}$ for $4 \mathrm{~h}$ and stored in an airer. The silica gel (60-200 mesh, Acros Organics USA) and neutral alumina (50200 mesh, Acros Organics USA) were activated at $180^{\circ} \mathrm{C}$ and $250^{\circ} \mathrm{C}$ for $12 \mathrm{~h}$, respectively, and then stored in an airer. All glassware were firstly treated with sulphochromic mixtures, and then washed successively with deionized water, HPLCgrade acetone, and hexane before use.

A stock solution of all target chemicals in a concentration of $10 \mathrm{mg} / \mathrm{ml}$ was prepared in methanol and stored in an amber glass vial at $-20^{\circ} \mathrm{C}$. The working solutions for the individual standards and their mixtures were achieved by serial dilution of stock solutions with pure $n$-hexane. These solutions were stored at $4^{\circ} \mathrm{C}$.

\section{Analytical procedures}

\section{Pretreatment of water samples}

Pretreatment of water samples was modified according to previous study (Zhou et al. 2009). Water samples were pre-filtered using $0.45-\mu \mathrm{m}$ APFF fiberglass filters (Millipore, Bedford, MA, USA) to eliminate particulate matter, then spiked with surrogate standard $\left(\mathrm{E} 2-\mathrm{d}_{3}\right)$ and adjusted to $\mathrm{pH}$ 3.0-4.0 using hydrochloric acid before extraction. The Oasis HLB cartridges were conditioned with $5 \mathrm{ml}$ of tert-butyl methyl ether, $5 \mathrm{ml}$ of methanol, and $5 \mathrm{ml}$ of DI water. Water samples were passed through the cartridge at a flow rate of 5-10 $\mathrm{ml} / \mathrm{min}$. The cartridge was prevented from drying out during loading of the water sample. The cartridge was then washed with $5 \mathrm{ml}$ of 
methanol/water $(25 / 75, v / v), 5 \mathrm{ml}$ of DI water, and $5 \mathrm{ml}$ of methanol/ammonia/DI water (10/2/88, $v / v)$, followed by vacuum to dry. Subsequently, $10 \mathrm{ml}$ of methanol/tert-butyl methyl ether (1/9, $v / v$ ) was used for elution of the SPE cartridges. Elution was gathered by the KD concentrator, hydrated by anhydrous sodium sulfate, and then dried to $0.5 \mathrm{ml}$ under a gentle stream of highpurity nitrogen in a $40^{\circ} \mathrm{C}$ water bath. Concentrated solution was clarified using a 5-g silicon gel and 5-g aluminum oxide filling column, which was packed wetly using $n$-hexane as the solvent. Approximately $2 \mathrm{ml}$ of methanol/acetone (50/50) was used to wash the KD concentrator and was transferred to filling column. The filling column was eluted by $10 \mathrm{ml}$ of methanol/acetone (50/50). The filling column elution reduced the volume to dryness under a gentle stream of high-purity nitrogen gas.

\section{Derivatization and instrumental analysis}

The derivatization and analytical conditions of the target compounds are described in previous research (Zhou et al. 2009). Briefly, the residues of water sample extractions were redissolved in $0.4 \mathrm{~mL}$ of hexane that contained $50 \mu \mathrm{l}$ of the derivatization mixture BSTFA/TCMS/TMSI (99:1:0.5, $v / v / v)$ and $50 \mathrm{ng} / \mathrm{ml}$ of pyrene-d $\mathrm{d}_{16}$. The derivatization was performed at $60^{\circ} \mathrm{C}$ for $30 \mathrm{~min}$. The derivatives were cooled to room temperature and stored at $4{ }^{\circ} \mathrm{C}$. Instrumental analysis was performed within 2 days.

The separation and detection of the target compounds were achieved by GC-MS (Agilent 6890 with mass spectrometer Agilent 5973 MSD, Agilent Technologies, USA). System control and data acquisition were achieved with ChemStation Software. One microliter of derivatives was injected into the HP-5 MS column $(30 \mathrm{~m} \times 0.25 \mathrm{~mm} \times$ $0.25 \mu \mathrm{m}$ film thickness) in splitless mode. Helium (99.9999\%) was used as the carrier gas, with the flow rate set at $1 \mathrm{ml} / \mathrm{min}$. Gas chromatographic temperature programs were as follows: initial temperature of $80^{\circ} \mathrm{C}$ held for $1 \mathrm{~min}$, increased to $200^{\circ} \mathrm{C}$ at a rate of $20^{\circ} \mathrm{C} / \mathrm{min}$, then increased to $300^{\circ} \mathrm{C}$ at a rate of $10^{\circ} \mathrm{C} / \mathrm{min}$ and held for $10 \mathrm{~min}$, with a total run of $27 \mathrm{~min}$ and solvent delay of $6 \mathrm{~min}$. The injector and detector temperatures were set at $280^{\circ} \mathrm{C}$. The ion source temperature was $230^{\circ} \mathrm{C}$, and the energy of the ionizing electron was $70 \mathrm{eV}$.

Quality assurance and quality control

All data were subject to strict quality control procedures. Before analysis, relevant standards were run to check column performance, peak height, resolution and sensitivity. With each set of samples analyzed, a solvent blank, a procedural blank, and a standard mixture of six estrogens were run in sequence to check contamination, peak identification, and quantification. No target compound was detected in the procedural blanks for water. Qualitative analysis of target compounds was accomplished on the basis of retention time and mass spectrum in a full scan model. Characteristic ions/quantification ions for each substance were $212,106 / 212$ for pyrene- $d_{16}, 412,397,383 / 412$ for DES, 342, 218, 257/342 for E1, 416, 285, 129/416 for $E 2,419$ for $E 2-d_{3}, 425,285,440 / 425$ for EE2, 504, 129, 345/504 for E3, and 428, 231, 244/428 for Ev, respectively. Quantitative analysis was performed in ion monitoring (SIM) mode using internal standard calibration. Initially, a series of target compound injections in the concentration range of 0.5 to $500 \mathrm{ng} / \mathrm{ml}$ with constant internal standard $(50 \mathrm{ng} / \mathrm{ml})$ were performed to determine linear concentration range. Good linearity was observed with correlation coefficients above 0.99 . Calibration curves were obtained by linear regression analysis to calculate unknown concentration.

Limit of detection (LOD) and limit of quantification (LOQ) were achieved by 1,250 times concentration and 5,000 times concentration for influent and effluent from the WWTPs. They were calculated as the minimum amount of a compound present in the sample that produced a signal to noise ratio of six, based on a $1-\mu$ l aliquot injection of the final $0.4 \mathrm{ml}$ extraction solution (Zhou et al. 2009). LOD and LOQ in water were $0.05-0.48$ and $1.2-3.6 \mathrm{ng} / \mathrm{l}$ for the influent and $0.02-0.26 \mathrm{ng} / \mathrm{l}$ and $0.06-0.78 \mathrm{ng} / \mathrm{l}$ for the effluent, respectively. The recovery study was performed on samples spiked with known levels of the estrogens $(100 \mathrm{ng} / \mathrm{l}$ for influent and $10 \mathrm{ng} / \mathrm{l}$ for effluent). Mean recoveries of estrogens were $78.9-108.0 \%$ for influent and 66.6-121.1\% for effluent. Relative standard devi- 
Table 3 Detectable ratios, minimum concentration, maximum concentration and mean concentration (SD) of estrogens selected in water samples (ng/L)

\begin{tabular}{llllll}
\hline Estrogens & $\begin{array}{l}\text { Detectable } \\
\text { ratios }\end{array}$ & Min & Max & Median & Mean (SD) \\
\hline DES & $10 / 17$ & nd & 11.1 & 0.1 & $1.6(3.2)$ \\
E1 & $17 / 17$ & 0.7 & $1.2 \times 10^{3}$ & 6.6 & $1.2 \times 10^{2}\left(2.9 \times 10^{2}\right)$ \\
E2 & $15 / 17$ & nd & 67.4 & 2.0 & $12.5(17.7)$ \\
EE2 & $16 / 17$ & nd & $4.1 \times 10^{3}$ & 4.7 & $2.5 \times 10^{2}\left(9.9 \times 10^{2}\right)$ \\
E3 & $11 / 17$ & nd & $1.2 \times 10^{3}$ & 1.9 & $1.4 \times 10^{2}\left(3.0 \times 10^{2}\right)$ \\
Ev & $5 / 17$ & nd & 11.2 & nd & $1.5(3.2)$ \\
\hline
\end{tabular}

ations (RSD) were 2.7-6.4\% for influent and 1.5$4.7 \%$ for effluent, respectively.

\section{Results and discussion}

Concentration levels of the six estrogens in different effluents

The concentrations of estrogens in different effluents varied from no detection (nd) to $11.1 \mathrm{ng} / \mathrm{l}, 0.7$ to $1.2 \times 10^{3} \mathrm{ng} / \mathrm{l}$, nd to $67.4 \mathrm{ng} / \mathrm{l}$, nd to $4.0 \times 10^{3} \mathrm{ng} / \mathrm{l}$, nd to $1.2 \times 10^{3} \mathrm{ng} / \mathrm{l}$, and nd to $11.2 \mathrm{ng} / \mathrm{l}$ for DES, E1, E2, EE2, E3, and Ev respectively. The mean concentration of DES, $\mathrm{E} 1, \mathrm{E} 2, \mathrm{EE} 2, \mathrm{E} 3$, and $\mathrm{Ev}$ were $1.6,1.2 \times 10^{2}$, $12.5,2.5 \times 10^{2}, 1.4 \times 10^{2}$, and $1.5 \mathrm{ng} / \mathrm{l}$, respectively (Table 3). As shown in Table 3, E1 was detectable in all samples, E2 and E3 detection exceeded $60 \%$, and $\mathrm{E} 1$ and $\mathrm{E} 3$ concentrations were higher than those of E2. The highest E3 concentration reached $1.2 \times 10^{3} \mathrm{ng} / \mathrm{l}$ in the WWTP inlet (site F), which was five times greater than that of E1.

For synthetic estrogens, EE2 was the highest detectable compound with concentration even to $4.1 \times 10^{3} \mathrm{ng} / \mathrm{l}$, while DES and Ev had relatively lower detectable ratios with concentrations less than $10 \mathrm{ng} / \mathrm{l}$. The total concentration of the six estrogens $\left(\sum 6 \mathrm{ES}\right)$ was highest in the effluent of the pharmaceutical factory $\left(4.4 \times 10^{3} \mathrm{ng} / \mathrm{l}\right)$ and WWTP inlets $\left(1.5 \times 10^{3} \mathrm{ng} / \mathrm{l}\right)$, and lowest in the fish pool $(2.1 \mathrm{ng} / \mathrm{l})$.

In comparison, the mean concentration of natural estrogens E1, E2, and E3 were $1.8 \times 10^{2}, 14.4$, and $1.4 \times 10^{2} \mathrm{ng} / \mathrm{l}$ in summer and $62.3,10.3$, and $1.3 \times 10^{2} \mathrm{ng} / \mathrm{l}$ in winter. The mean concentration of synthetic estrogens DES, EE2, and Ev were 1.1, 14.6, and $1.6 \mathrm{ng} / \mathrm{l}$ in summer and 2.3, $5.1 \times 10^{2}$, and $1.4 \mathrm{ng} / \mathrm{l}$ in winter. Higher mean concentrations of natural estrogens occurred in summer, and higher mean concentrations of synthetic estrogens presented in winter, except Ev (Fig. 2).

In the WWTP inlet, the mean concentration of natural estrogens E1, E2, and E3 and synthetic estrogen EE2 were 171.4, 46.6, $8.3 \times 10^{2}$, and $15.0 \mathrm{ng} / \mathrm{l}$, respectively, for site $\mathrm{F}$ and $1.2 \times$ $10^{2}, 7.2,1.2 \times 10^{2}$, and $16.2 \mathrm{ng} / \mathrm{l}$, respectively, for site $G$ (Table 4). Concentrations of DES and Ev were below $8 \mathrm{ng} / \mathrm{l}$. In previous publications (Table 4), the reported concentrations of natural and synthetic estrogens in WWTP inlets hardly ever exceeded $100 \mathrm{ng} / \mathrm{l}$. In the present study, however, estrogen concentrations were high, which was likely due to the larger population and lower per capital water volume consumption of Beijing. Conversely, however, the relative ratios of E1, E2, $\mathrm{E} 3$, and EE2 in the WWTP inlets in Beijing were quite similar to those found in previous studies in Spain and Italy (Baronti et al. 2000; Petrovic et al. 2002). Concentrations of the six estrogens in the two WWTP effluents were about $10 \mathrm{ng} / \mathrm{l}$, lower than those observed in Spain, France, Italy, Australia,

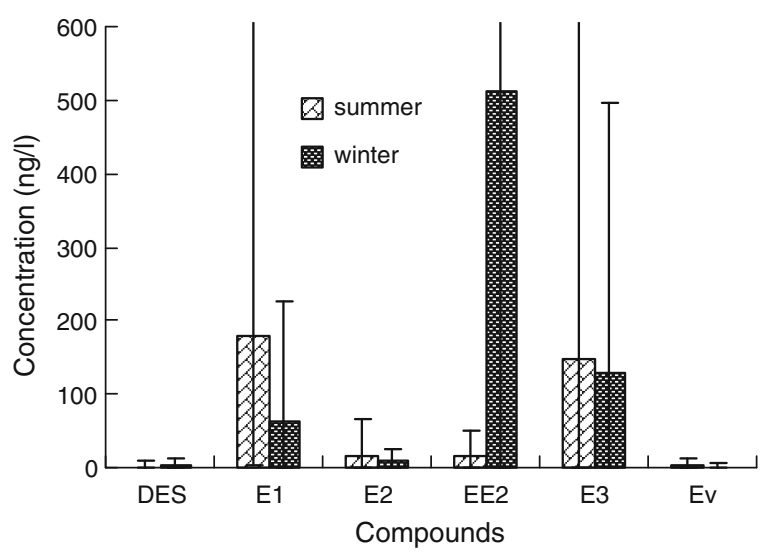

Fig. 2 Mean concentration of six estrogens in all sampling sites in summer and winter 


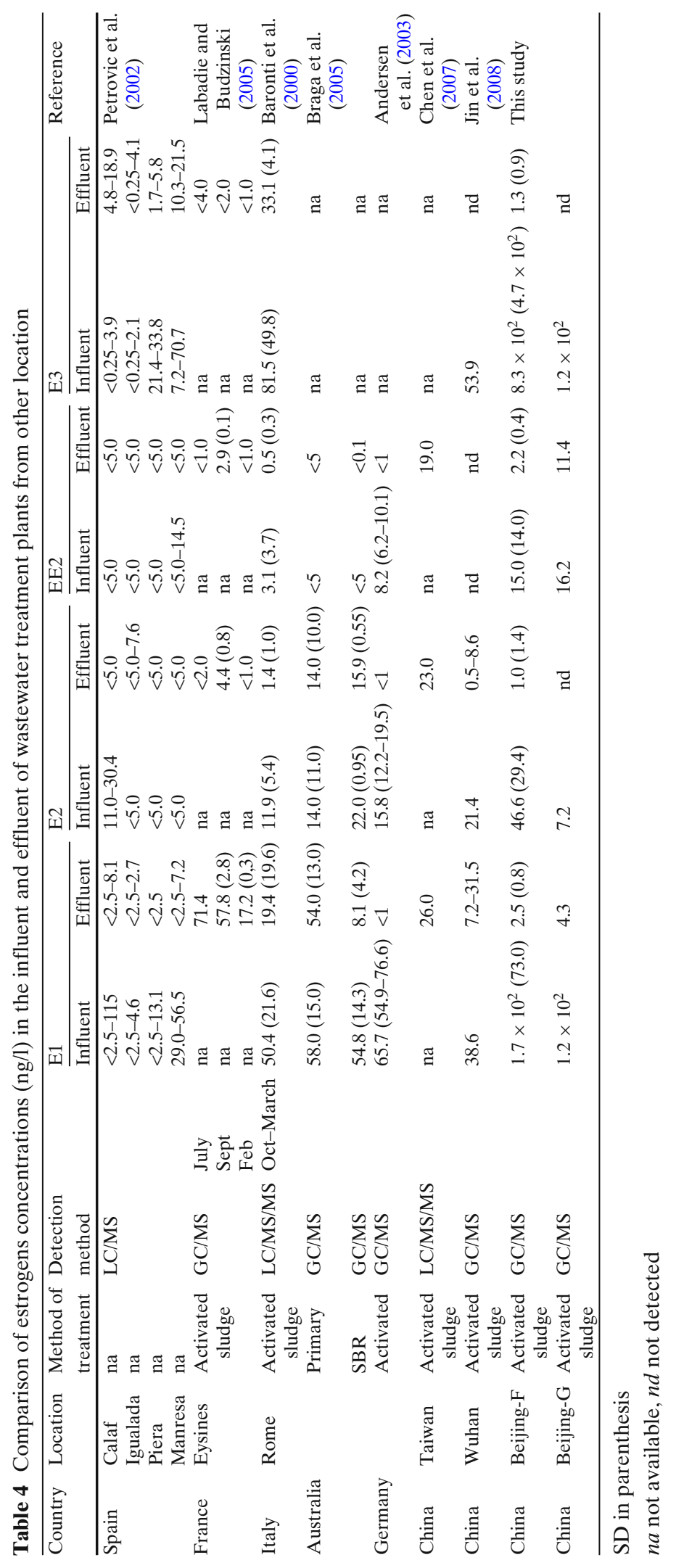


Germany, and other cities in China (Lee and Peart 1998; Baronti et al. 2000; Petrovic et al. 2002; Andersen et al. 2003; Braga et al. 2005; Pierre and Hélène 2005; Chen et al. 2007, Jin et al. 2008). With the exception of EE2, the removal rates of $\mathrm{E} 1, \mathrm{E} 2$, and E3 in the two WWTPs exceeded 90\% in both summer and winter, showing that natural estrogens were eliminated effectively by conventional activated sludge treatment processes. In the two WWTPs, however, EE2 demonstrated a lower removal rate $(51 \%)$ in winter and summer $(29.6 \%)$. Previous work has revealed that EE2 is more persistent than natural estrogens in conventional WWTPs (Layton et al. 2000). A few reports indicate that for activated sludge treatment, sorption and biodegradation are the principal mechanisms for estrogen removal. Sorption of estrogens to sludge is important for the removal of hydrophobic compounds in the aqueous phase. For more hydrophilic compounds such as E1 and E3, however, the case may be inversed. In addition, biodegradation generally depends on factors such as bacteria, sludge retention times, and temperature (Layton et al. 2000; Johnson and Sumpter 2001; Andersen et al. 2003).

\section{Source identification}

Most published data has focused on E1, E2, and EE2 due to their higher estrogenic activity. To date, however, E3 has been largely ignored though it is found at relatively higher concentrations (Andersen et al. 2003; Braga et al. 2005; Chen et al. 2007). Occurring mainly in the water phase, E3 is a hydrophilic compound most commonly resulting from human excretion. Previous research has measured E3 concentrations in the urine of pregnant women as high as $4.0 \times 10^{3} \mu \mathrm{g} / \mathrm{d}$, seven times the concentration of E1 and accounting for $38 \%$ of total natural estrogens (E1 + E2 + E3) for menstruate women and about $24 \%$ for menopausal women (D'Ascenzo et al. 2003). The E3 concentration also accounted for about 21\% of urinal excretion by males, based on Johnson's assumption that males excrete $3.9 \mu \mathrm{g} \mathrm{E} 1,1.6 \mu \mathrm{g}$ $\mathrm{E} 2$, and $1.5 \mu \mathrm{g}$ E3 per day (Johnson et al. 2000). In general, males, menstruate women, menopausal women, and pregnant women are the main donors of natural estrogen. Therefore, the ratio of E3 to total natural estrogens can be used as an indicator in source identification of effluent estrogens. We used E3/(E1 + E2 + E3) as an indicator to trace human estrogens excretion (hE). When hE exceeded 0.2, we attributed the natural estrogens in the effluents to human excretion.

From Fig. 3, the $\mathrm{hE}$ in sampling sites $\mathrm{C}$ (hospital) and F and G (WWTPs) exceeded 0.4, which indicated that estrogens in the hospital wastewater and WWTP inlets came mainly from human excretion.

No E3 was observed in sampling sites A (fish pool) and E (hennery), showing that estrogens in the fish pool and the hennery were not from human excretion. In commercial fish production, estrogens are often used directly in feminization. Mean concentrations of E1 and E2 in the fish pool were 1.8 and $0.4 \mathrm{ng} / \mathrm{l}$, respectively, either from use of reclaimed water or from application of estrogens in fish production. Higher concentrations of EE2 (48.8 ng/l) were found in the hennery wastewater, which proved the usage of estrogens in chicken production. In this case, the calculated $\mathrm{hE}$ was zero, indicating no contribution from human excretion.

At site D (pharmaceutical factory), a higher concentration of E1 $\left(1.2 \times 10^{3} \mathrm{ng} / \mathrm{l}\right)$ was observed in summer and a higher concentration of EE2 $\left(4.1 \times 10^{3} \mathrm{ng} / \mathrm{l}\right)$ was observed in winter. We know that EE2 can be easily photochemical degradation to E1, especially at higher temperatures (Zuo

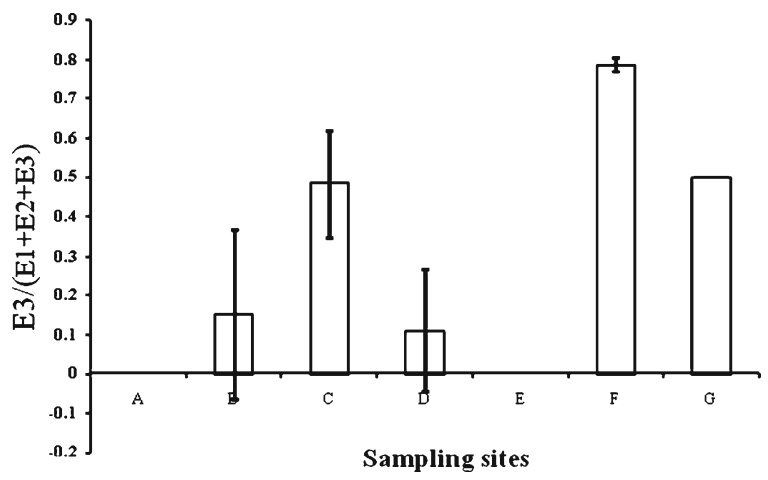

Fig. 3 Human excretion value $(\mathrm{E} 3 /(\mathrm{E} 1+\mathrm{E} 2+\mathrm{E} 3))$ in selected sampling sites ( $A$ fish pool, $B$ chemical plant, $C$ hospital, $D$ pharmaceutical factory, $E$ hennery, $F, G$ wastewater treatment plant) 
et al. 2005). Our previous work reported higher concentrations of EE2 in the effluent of this pharmaceutical factory, with the intermediate of EE2 degradation being oxygenized to E1 (Ren et al. 2007). Higher concentrations of EE2 in the pharmaceutical factory wastewater may be due to incomplete recovery of this major contraceptive pill ingredient. The $\mathrm{hE}$ values in the pharmaceutical factory wastewater were zero in summer and 0.22 in winter. This indicates that natural estrogens in the pharmaceutical factory wastewater were contributed by EE2 biodegradation in summer and by human excretion in winter. It may be due to rapid biodegradation of E3 in sewer and wastewater treatment facilities of pharmaceutical factory in summer.

Compared with the WWTPs, concentrations of natural estrogens in sampling site $C$ (chemical plant) were lower and $\mathrm{hE}$ (zero in summer and 0.3 in winter) was smaller, indicating the effluent was a mixture of municipal and industrial wastewater. The lower hE in summer can also be concluded to rapid biodegradation of $\mathrm{E} 3$.

\section{Loads to the receiving waters}

In 2005, the disposed volume of wastewater was 70.15 million cubic meters, accounting for $62.4 \%$ of total collected wastewater in Beijing (Beijing Statistical Yearbook 2006). On this basis, it can be estimated that more than $40 \%$ of natural estrogen and $60 \%$ of EE2 in wastewater may be entering the receiving water. For natural estrogens, direct discharge without any treatment accounts for $90 \%$ of that entering receiving water. Due to lower removal rates for synthetic estrogen EE2, however, direct discharge without treatment accounts for $40 \%$ of that entering receiving water. In addition, industrial and municipal wastewaters receiving no treatment before discharge are an important source of estrogenic activity (Ma et al. 2008).

Based on the data in Table 4, it can be estimated that mean concentrations of E1, E2, E3, and EE2 in receiving water should be in the range of 48 to $70 \mathrm{ng} / \mathrm{l}, 2$ to $19 \mathrm{ng} / \mathrm{l}, 50$ to $320 \mathrm{ng} / \mathrm{l}$, and 6 to $7 \mathrm{ng} / \mathrm{l}$, respectively The mean concentrations of DES and Ev should be below $10 \mathrm{ng} / \mathrm{l}$. This estimation is based on the assumptions that the estrogens are de-conjugated in wastewater, all WWTPs have similar steroid estrogen removal rates, and sorption and degradation of estrogens in receiving water can be ignored. Although these assumptions are not implausible, our estimation accorded with survey data reported for three rivers near Beijing (Lei et al. 2009).

\section{Conclusions}

This study indicated that natural estrogens E1, E2, and E3 and synthetic estrogen EE2 were the dominant steroid estrogens in different effluents in Beijing. For source identification, an indicator (hE) was used to trace human estrogen excretion. The hE in effluents from the hospital and WWTP inlets exceeded 0.4, but were much smaller for other effluents. It shows that human excretions were major contributors of natural estrogens in municipal wastewater.

Based on discharge and disposed wastewater volumes in 2005, as well as the WWTP removal rates in this study, we estimated that more than $40 \%$ of natural estrogen and $60 \%$ of EE2 in wastewater may be entering receiving water. Of this, direct discharge accounted for about $90 \%$ for natural estrogens and $40 \%$ for synthetic estrogen EE2. The mean concentrations of E1, E2, E3, and EE2 in the receiving water predicted ranged from 48 to $70 \mathrm{ng} / \mathrm{l}, 2$ to $19 \mathrm{ng} / \mathrm{l}, 50$ to $320 \mathrm{ng} / \mathrm{l}$, and 6 to $7 \mathrm{ng} / \mathrm{l}$, respectively. The mean concentrations of DES and Ev are expected to be below $10 \mathrm{ng} / \mathrm{l}$.

Acknowledgements We thank Dr. Jun Zhou for providing us with the information on the WWTPs. This work was supported by the Chinese Academy of Sciences (KZCX1YW-06) and the National Basic Research Program of China (2007CB407301).

\section{References}

Andersen, H., Siegrist, H., Halling-Sorensen, B., \& Ternes, T. A. (2003). Fate of estrogens in a municipal sewage treatment plant. Environmental Sciences and Technology, 37, 4021-4026.

Baronti, C., Curini, R., D'Ascenzo, G., Di, C. A., Gentili, A., \& Samperi, R. (2000). Monitoring natural and synthetic estrogens at activated sludge sewage treatment plants and in a receiving river water. Environmental Sciences and Technology, 34, 5059-5066. 
Beardmore, J. A., Mair, G. C., \& Lewis, R. I. (2001). Monosex male production in finfish as exemplified by tilapia: Applications, problems, and prospects. Aquaculture, 197, 283-301.

Beijing Statistical Yearbook (2006). Beijing Municipal Bureau of Statistics. www.bjstats.gov.cn/tjnj/2006-tjnj/ content/mV98_08-10.htm.

Belfroid, A., Van der, H. A., Vetaak, A., Schäfer, A., Rijs, G., Wegener, J., et al. (1999). Analysis and occurrence of estrogenic hormones and their glucuronides in surface water and waste water in the Netherlands. Science of the Total Environment, 225, 101-108.

Braga, O., Smythe, G., Schafer, A. I., \& Feitz, R. J. (2005). Fate of steroid estrogens in Australian inland and coastal wastewater treatment plants. Environmental Sciences and Technology, 39, 3351-3358.

Brown, N., Nagarkatti, M., \& Nagarkatti, P. S. (2006). Diethylstilbestrol alters positive and negative selection of $\mathrm{T}$ cells in the thymus and modulates T-cell repertoire in the periphery. Toxicology and Applied Pharmacology, 212, 119-126.

Campbell, C. G., Borglin, S. E., Green, F. B., Grayson, A., Wozei, E., \& Stringfellow, W. T. (2006). Biologically directed environmental monitoring, fate, and transport of estrogenic endocrine disrupting compounds in water: A review. Chemosphere, 65, 1265-1280.

Chen, C., Wen, T., Wang, G., Cheng, H., Lin, Y., \& Lien, G. W. (2007). Determining estrogenic steroids in Taipei waters and removal in drinking water treatment using high-flow solid-phase extraction and liquid chromatography/tandem mass spectrometry. Science of the Total Environment, 378, 352-365.

D'Ascenzo, G., Di, C. A., Gentili, A., Mancini, R., Mastropasqua, R., Nazzari, M., et al. (2003). Fate of natural estrogen conjugates in municipal sewage transport and treatment facilities. Science of the Total Environment, 302, 199-209.

Desbrow, C., Routledge, E. J., Brighty, G. C., Sumpter, J. P., \& Waldock, M. (1998). Identification of estogenic chemicals in STW effluent. 1. Chemical fractionation and in vitro biological screening. Environmental Sciences and Technology, 32, 1549-1558.

Ford, C. D., Johnson, G. H., \& Smith, W. G. (1983). Natural killer cells in in utero diethylstilbesterol-exposed patients. Gynecologic Oncology, 16, 400-404.

Giusti, R. M., Iwamoto, K., \& Hatch, E. E. (1995). Diethylstilbestrol revisited: A review of the long-term health effects. Annals Internal Medicine, 122, 778-788.

Gomes, R. L., Acioglu, E., Scimshaw, M. D., \& Lester, J. N. (2004). Steroid estrogen determination in sediment and sewage sludge: A critique of sample preparation and chromatographic/mass spectrometry considerations, incorporating a case study in method development. Trends in Analytical Chemistry, 23, 737-744.

Hansen, P. D., Dizer, H., Hock, B., Marx, A., Sherry, J., McMaster, M., et al. (1998). Vitellogenin-a biomarker for endocrine disruptors. Trends in Analytical Chemistry, 17, 448-451.

Hurley, M. A., Matthiessen, P., \& Pickering, A. D. (2004). A model for environmental sex reversal in fish. Journal of Theoretical Biology, 227, 159-165.
Jin, S., Yang, F., Liao, T., Hui, Y., \& Xu Y. (2008). Seasonal variations of estrogenic compounds and their estrogenicities in influent and effluent from a municipal sewage treatment plant in China. Environmental Toxicology and Chemistry, 27, 146-153.

Johnson, A. C., Belfroid, A., \& Di Corcia, A. (2000). Estimating steroid oestrogen inputs into activated sludge treatment works and observations on their removal from the effluent. Science of the Total Environment, 256(2-3), 163-173.

Johnson, A. C., \& Sumpter, J. P. (2001). Removal of endocrine-disrupting chemicals in activated sludge treatment works. Environmental Sciences and Technology, 35, 4697-4703.

Labadie, P., \& Budzinski, H. (2005). Determination of steroidal hormone profiles along the Jalle d'Eysines River (near Bordeaus, France). Environmental Sciences and Technology, 39, 5113-5120.

Labadie, P., \& Budzinski, H. (2006). Alteration of steroid hormone profile in juvenile turbot (Psetta maxima) as a consequence of short-term exposure to $17 \mathrm{a}$ ethynylestradiol. Chemosphere, 64, 1274-1286.

Lai, K. M., Johnson, K. L., Scrimshaw, M. D., \& Lester, J. N. (2000). Binding of water borne steroid estrogens to solid phases in river and estuarine systems. Environmental Sciences and Technology, 34, 3890-3894.

Layton, A. C., Gregory, B. W., Seward, J. R., Schultz, T. W., \& Sayler, G. S. (2000). Mineralization of steroidal hormones by biosolids in wastewater treatment systems in Tennessee U.S.A. Environmental Sciences and Technology, 34, 3925-3931.

Lee, H. B., \& Peart, T. E. (1998). Determination of $17 \beta$ estradiol and its metabolites in sewage effluent by solid phase extraction and gas chromatography/mass spectrometry. The Journal of AOAC International, 81(6), 1209-1216.

Lei, B., Huang, S., Zhou, Y., Wang, D., \& Wang, Z. (2009). Levels of six estrogens in water and sediment from three rivers in Tianjin area, China. Chemosphere, 76, 36-42.

Legler, J. (2001). Development and application of in vitro and in vivo reporter gene assays for the assessment of (xeno-) estrogenic compounds in the aquatic environment. Department of Toxicology, Wageningen University.

Legler, J., Dennekamp, M., Vethaak, A. D., \& Brouwer, A. (2002). Detection of estrogenic activity in sedimentassociated compounds using in vitro reporter gene assays. Science of the Total Environment, 293, 69-83.

Lintelmann, J., Katayama, A., Kurihara, N., Shore, L., \& Wenzel, A. (2003). Endocrine disruptors in the environment. Pure and Appllied Chemistry, 75, 631-681.

Ma, M., Rao, K., \& Wang, Z. (2008). Occurrence of estrogenic effects in sewage and industrial wastewaters in Beijing, China. Environmental Pollution, 147, 331336.

Maggs, J. L., Grimmer, S. F. M., L' e-Orme, M., Breckerridge, A. M., Park, B. K., \& Gilmore, I. T. (1983). The biliary and urinary metabolites of $\left[{ }^{3} \mathrm{H}\right]$ 17a-ethynylestradiol in women. Xenobiotica, 13, 421-431. 
Orlando, E. F., Kolok, A. S., Binzcik, G. A., Gates, J. L., Horton, M. K., Lambright, C. S., et al. (2004). Endocrine-disrupting effects of cattle feedlot effluent on an aquatic sentinel species, the fathead minnow. Environmental Health Perspectives, 112, 353-358.

Petrovic, M., Solé, M., de Alda, M. J. L., \& Barceló, D. (2002). Endocrine disruptors in sewage treatment plants, receiving river waters, and sediments: Integration of chemical analysis and biological effects pm feral carp. Environmental Toxicology Chemistry, 21, 2146-2156.

Pierre, L., \& Hélène, B. (2005). Determination of steroidal hormone profiles along the Jalle d'Eysines River (near Bordeaux, France). Environmental Sciences and Technology, 39, 5113-5120.

Purdom, C. E., Hardiman, P. A., Bye, V. J., Eno, N. C., Tyler, C. R., \& Sumpter, J. P. (1994). Estrogenic effects of effluents from sewage treatment works. Chemical Ecology, 8, 275-285.

Ranney, R. E. (1977). Comparative metabolism of 17aethynyl steroids used in oral contraceptives. Journal of Toxicology and Environmental Health, 3, 139166.

Reed, M. J., Fotherby, K., \& Steele, S. J. (1972). Metabolism of ethynyloestradiol in man. Journal of Endocrinology, 55, 351-361.

Ren, H., Ji, S., Naeem ud din, A., Wang, D., \& Cui, C. (2007). Degradation characteristics and metabolic pathway of 17a-ethynylestradiol by Sphingobacterium sp. JCR5. Chemosphere, 66(2), 340-346.

Routledge, E. J., Sheahan, D., Desbrow, C., Brighty, G. C., Waldock, M., \& Sumpter, J. P. (1998). Identification of estrogenic chemicals in STW effluent. 2. In vivo responses in trout and roach. Environmental Sciences and Technology, 32, 1559-1565.

Soto, A. M., Calabro, J. M., Prechtl, N. V., Yau, A. Y., Orlando, E. F., Daxenberger, A., et al. (2004).
Androgenic and estrogenic activity in water bodies receiving cattle feedlot effluent in eastern Nebraska, USA. Environmental Health Perspectives, 112, 346352.

Sun, Q., Deng, S., Huang, J., Shen, G., \& Yu, G. (2007). Contributors to estrogenic activity in wastewater from a large wastewater treatment plant in Beijing, China. Environmental Toxicology and Pharmacology, 25, 20-26.

Strussmann, C. A., Takshima, F., \& Toda, K. (1996). Sex differentiation and hormonal feminization in pejerrey Odontesthes bonariensis. Aquaculture, 139, 31-45.

Ternes, T. A., Kreckel, P., \& Mueller, J. (1999). Behaviour and occurrence of estrogens in municipal sewage treatment plants II. Aberobic batch experiments with activated sludge. Science of the Total Environment, 255, 91-99.

Travis, A. H., Donald, A. G., \& Ann, C. W. (2003). Manure-borne estrogens as potential environmental contaminants: Review. Environmental Sciences and Technology, 37, 5471-5478.

Zha, J., Sun, L., Zhou Y., Phlip, A. S., Ma, M., \& Wang, Z. (2008). Assessment of 17 a-ethinylestradiol effects and underlying mechanisms in a continuous, multigeneration exposure of the Chinese rare minnow (Gobiocypris rarus). Toxicology and Appllied Pharmacology, 226, 298-308.

Zhou, Y., Zhou, J., Xu, Y., Zha, J., Ma, M., \& Wang, Z. (2009). An alternative method for the determination of estrogens in surface water and wastewater treatment plant effluent using pre-column trimethylsilyl derivatization and gas chromatography/mass spectrometry. Environmental Monitoring and Assessment, 158, 35-49.

Zuo, Y., Zhang, K., \& Deng, Y. (2005). Occurrence and photochemical degradation of 17a-ethinylestradiol in Acushnet river estuary. Chemosphere, 63, 1583-1590. 